\title{
Peningkatan Hasil Belajar Materi Keunggulan Lokasi Indonesia Melalui Pendekatan Problem Based Learning pada Siswa Kelas VII B SMPN 6 Kota Bima
}

\author{
Sitti Rahmah ${ }^{1}$ \\ ${ }^{1}$ SMPN 6 Kota Bima \\ Email: ${ }^{1}$ sittirahmah@gmail.com
}

\begin{tabular}{l}
\hline Tersedia Online di \\
http://www.jurnal.unublitar.ac.id/ \\
index.php/briliant \\
\hline \\
\hline Sejarah Artikel \\
Diterima pada 11 Februari 2018 \\
Disetuji pada 11 Februari 2018 \\
Dipublikasikan pada 13 Februari \\
2018 Hal. $92-100$
\end{tabular}

\section{Kata Kunci:}

hasil belajar, keunggulan lokasi

Indonesia, problem based

learning

\section{DOI:}

http://dx.doi.org/10.28926/briliant .v3i1.145

\begin{abstract}
Abstrak: Berdasarkan hasil observasi yang dilakukan di Kelas VIII B pada waktu pembelajaran IPS diperoleh hasil bahwa Hasil belajar siswa kurang memuaskan, yaitu dari 33 siswa hanya 10 siswa yang nilainya dapat mencapai $\mathrm{KKM}$ atau $\geq 70$, sedangkan 23 siswa lainnya masih belum dapat mencapai KKM atau $\leq 69$. Untuk itu agar dapat meningkatkan hasil belajar siswa dalam menyelesaikan soal tentang Keunggulan lokasi Indonesia serta untuk tercapainya tujuan pembelajaran perlu diadakan perbaikan pembelajaran dengan menerapkan Pendekatan Problem based learning. Penerapan pembelajaran Keunggulan lokasi Indonesia melalui Pendekatan Problem based learning dapat meningkatkan Hasil belajar siswa Kelas VIII B SMP Negeri 6 Kota Bima dan dapat mempermudah siswa dalam menyelesaikan persoalan Keunggulan lokasi Indonesia
\end{abstract}

IPS adalah tentang konsep-konsep dan struktur-struktur IPS yang terdapat dalam materi-materi yang dipelajari serta menjalankan hubungan antara konsep-konsep dan struktur-struktur itu. Lain dari itu peserta didik lebih mudah mengingat IPS itu, bila yang dipelajari merupakan pola yang terstruktur. Keberhasilan pembelajaran IPS tersebut tergantung pada siswa dalam proses belajar mengajar, sedangkan keberhasilan siswa tidak hanya tergantung pada sarana dan prasarana pendidikan, serta kurikulumnya. Akan tetapi, Guru dalam proses pembelajaran juga dapat mempengaruhi peningkatan prestasi belajar IPS siswa, salah satunya dengan penggunaan metode pembelajaran yang tepat oleh Guru sesuai dengan materi yang disampaikan.

Mata pelajaran IPS menuntut kemampuan Guru untuk bisa membuat siswa mengerti dan memahami tentang materi yang diajarkan dengan tidak hanya membaca buku dan teori saja melainkan harus disertai alat peraga, contoh, praktek, latihan soal, seperti soal bercerita dan sebagainya, agar siswa memiliki pengetahuan, keterampilan dan bahkan sikap ilmiah yang berujung pada pemerolehan hasil belajar yang maksimal.

Berdasarkan hasil pengamatan dalam proses belajar mengajar dikelas, keadaan sekolah, dan melalui peninjauan bidang akademik dan non akademik, diperoleh hasil bahwa keadaan SMP Negeri 6 Kota Bima khususnya siswa Kelas VIII B tahun ajaran 2015/2016 dalam pelajaran IPS belum menunjukkan hasil belajar sesuai dengan KKM yang ditetapkan terutama pada materi pelajaran Keunggulan lokasi Indonesia. Padahal, ditinjau dari keadaan fisik sekolah, yaitu 
ruang Kelas VIII B sudah baik dan sesuai sebagai tempat berlangsungnya proses belajar mengajar. Pengamatan pada proses pembelajaran oleh peneliti dapat disimpulkan bahwa pelaksanaan proses belajar mengajar lah yang belum membuat siswa aktif belajar, sehingga kemampuan siswa belum tergali dengan maksimal.

Pada ulangan harian IPS dengan materi Keunggulan lokasi Indonesia, di dapat rata-rata nilai sebesar 62,6 dari 33 siswa, padahal Kriteria Ketuntasan Minimalnya (KKM) telah ditentukan nilai sebesar 70. Dan hanya 10 siswa yang mendapat nilai di atas 70 . Hal ini berarti, hanya 30,3\% dari siswa yang telah mencapai ketuntasan belajar, dan yang lainnya memiliki prestasi belajar yang rendah. Hasil belajar merupakan bagian terpenting dalam pembelajaran. Nana Sudjana (2009: 3) mendefinisikan hasil belajar siswa pada hakikatnya adalah perubahan tingkah laku sebagai hasil belajar dalam pengertian yang lebih luas mencakup bidang kognitif, afektif, dan psikomotorik. Dimyati dan Mudjiono (2006: 3-4) juga menyebutkan hasil belajar merupakan hasil dari suatu interaksi tindak belajar dan tindak mengajar. Dari sisi guru, tindak mengajar diakhiri dengan proses evaluasi hasil belajar. Dari sisi siswa, hasil belajar merupakan berakhirnya pengajaran dari puncak proses belajar.

Oleh karena itu, demi memperbaiki berbagai masalah yang ada, peniliti memerlukan suatu solusi untuk mengatasi hambatan-hambatan yang terjadi. Akhirnya diputuskan dengan menggunakan pendekatan problem based learning dalam pembelajaran IPS ini. Pendekatan problem based learning adalah cara penyajian pelajaran yang memberikan kesempatan kepada peserta didik untuk mencari dan menemukan informasi dengan atau tanpa bantuan Guru.

Boud \& Felleti (1991) menyatakan bahwa Problem Based Learning is a way of constructing and teaching course using problem as a stimulus and focus on student activity. H.S. Barrows (1982:88) menyatakan bahwa PBL adalah sebuah metode pembelajaran yang didasarkan pada prinsip bahwa masalah (problem) dapat digunakan sebagai titik awal untuk mendapatkan atau mengintegrasikan ilmu (knowledge) baru. Dengan demikian, masalah yang ada digunakan sebagai sarana agar anak didik dapat belajar sesuatu yang dapat menyokong keilmuannya. PBL adalah proses pembelajaran yang titik awal pembelajarannya berdasarkan masalah dalam kehidupan nyata lalu dari masalah ini siswa dirangsang untuk mempelajari masalah berdasarkan pengetahuan dan pengalaman yang telah mereka punyai sebelumnya (prior knowledge) sehingga dari prior knowledge ini akan terbentuk pengetahuan dan pengalaman baru. Diskusi dengan menggunakan kelompok kecil merupakan poin utama dalam penerapan PBL.

Dengan menggunakan pendekatan PBL ini, siswa akan bekerja secara kooperatif dalam kumpulan untuk menyelesaikan masalah sebenarnya dan yang paling penting membina kemahiran untuk menjadi siswa yang belajar secara sendiri. Pembelajaran berpusat pada siswa, sehingga siswa diharapkan lebih aktif, antusias, dan berani dalam mencari penyelesaian permasalahan yang dihadapinya, serta memungkinkan siswa menemukan sendiri informasi-informasi yang diperlukan untuk mencapai tujuan belajarnya, sehingga hasil belajar siswa pun dapat meningkat.

Sehingga tujuan dari penelitian ini adalah untuk mengetahui (1) bagaimana penerapan pendekatan problem based learning untuk meningkatkan hasil belajar materi keunggulan lokasi Indonesia pada siswa kelas V SDN 6 Kota 
Bima. (2) Apakah pendekatan problem based learning dapat meningkatkan hasil belajar materi keunggulan lokasi Indonesia pada siswa kelas V SDN 6 Kota Bima

\section{METODE}

Penelitian tindakan sekolah ini dilaksanakan di ruang Kelas VIII B SMP Negeri 6 Kota Bima. pada semester I, pada tanggal 8 Agustus 2015 sampai dengan 15 Agustus 2015. Dalam penelitian ini subjek yang digunakan adalah adalah seluruh siswa Kelas VIII B SMP Negeri 6 Kota Bima tahun pelajaran 2015/2016 sebanyak 33 siswa yang terdiri dari 15 siswa putra dan 18 siswa putri. Penelitian ini dilakukan dengan dua siklus, dimana masing-masing siklus dikenai perlakuan yang sejenis dengan bobot yang beda. Dibuat dua siklus dimaksudkan untuk memperbaiki system pengajaran yang dilaksanakan.

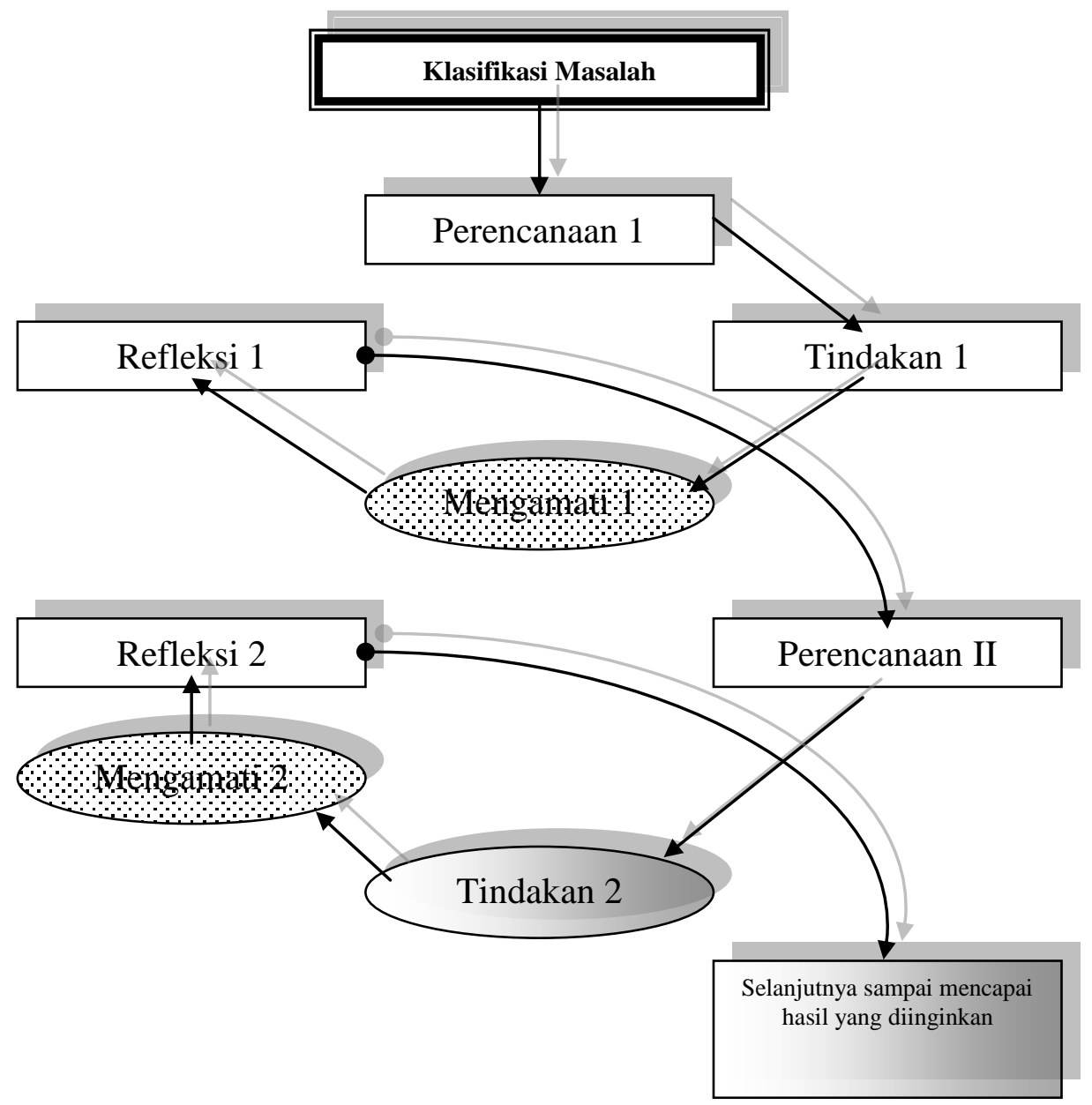

Gambar 1 Langkah-Langkah PTK dengan 2 Siklus

Adapun ragam instrument penelitian tindakan kelas yang telah dipersiapkan yaitu, Rencana Pelaksaaan Pembelajaran sebagai instrument rencana pelaksanaan tindakan. Lembar observasi Guru sebagai instrument utama pengumpul data proses dan lembar observasi siswa, wawancara, angket dan catatan lapangan sebagai instrument pendukung pengumpul data proses. Selain itu juga terdapat instrument pengumpul data hasil, yang dapat dikumpulkan dari hasil 
belajar berdasarkan soal-soal yang diberikan, serta ketrampilan siswa berdasarkan rubrik yang ada.

Teknik analisis yang digunakan yaitu deskriptif persentase. Data hasil penelitian yang dianalisis meliputi rata-rata kelas, ketuntasan belajar individu dan ketuntasan belajar secara klasikal. Selanjutnya hasil analisis data diperoleh baik secara kualitatif (dengan kata-kata) dan kuantitatif (dengan grafik). Hasil ini diinterprestasikan dan disimpulkan untuk menjawab permasalahan yang ada. Analisis data dari sumber-sumber informasi hasil penelitian di dapat dari: (1) Analisis dara observasi, Data hasil observasi keterlaksanaan pembelajaran melalui pendekatan problem based learning dan observasi aktivitas siswa dianalisis secara deskriptif untuk memberikan gambaran pelaksanaan pembelajaran dengan menggunakan pendekatan problem based learning. (2) analisis data wawancara, Hasil wawancara dengan siswa dianalisi secara deskriptif dengan lembar angket untuk mengetahui pendapat Guru dan siswa terhadap pembelajaran dan (3) analisis data tes.

\section{HASIL}

\section{Siklus I}

Dalam pelaksanaan pembelajaran, Guru masih menghadapi berbagai kendala, antara lain: (1) Masih ada siswa yang tidak membawa peralatan pembelajaran seperti yang telah ditugaskan. (2) Masih ada kelompok yang bingung dalam mengikuti langkah-langkah yang tertera dalam lembar kegiatan. (3) Masih ada beberapa siswa yang belum aktif dalam pelaksanaan percobaan. (4) Kurangnya sumber referensi bagi satu kelompok. (5) Ketika pelaksanaan diskusi, ada beberapa siswa yang tidak aktif menyampaikan pendapatnya. (6) Dalam menyimpulkan hasil percobaan, terdapat 4 (empat) kelompok yang malu untuk presentasi, dan hanya terdapat 2 (dua) siswa yang mengajukan pertanyaan.

Adapun prosentase hasil observasi dalam pelaksanaan percobaan pada siklus I dapat dilihat dari tabel 3 bawah ini. Perhitungan prosentase keberhasilan siklus I di bawah ini diskusikan juga dengan teman sejawat.

Tabel 1 Prosentase Hasil Observasi Siklus I

\begin{tabular}{|l|l|l|}
\hline No & Kegiatan Siswa & Prosentase \\
\hline 1 & Kelengkapan menyiapkan alat dan bahan percobaan & $30 \%$ \\
\hline 2 & Keruntutan langkah-langkah dalam pelaksanaan kegiatan percobaan & $52 \%$ \\
\hline 3 & Keaktifan siswa selama melaksanakan kegiatan percobaan & $57 \%$ \\
\hline 4 & Keaktifan siswa dalam mengutarakan pendapat saat berdiskusi & $43 \%$ \\
\hline 5 & Kesimpulan akhir sesuai percobaan & $46 \%$ \\
\hline
\end{tabular}

Hasil post test pada siklus pertama dapat menjadi perhitungan persentase peningkatan prestasi belajar siswa. Dengan acuan penilaian tetap berdasarkan nilai KKM yang telah ditetapkan yaitu paling sedikit siswa memperoleh nilai 70 . Adapun rekapitulasi hasil test siklus I adalah sebagai berikut:

Tabel 2 Hasil Post Test Siklus Pertama

\begin{tabular}{|l|l|l|}
\hline No & Deskripsi & Nilai \\
\hline 1 & Jumlah Nilai & 2385 \\
\hline 2 & Rata-rata Hasil Post Test & 72,3 \\
\hline
\end{tabular}




\begin{tabular}{|l|l|l|}
\hline 3 & Jumlah siswa yang mendapat nilai diatas KKM (70) & 20 \\
\hline 4 & Presentase siswa yang mendapat nilai diatas KKM (70) & $60,6 \%$ \\
\hline 5 & Jumlah siswa yang mendapat nilai dibawah KKM (70 & 13 \\
\hline 6 & Presentase siswa yang mendapat nilai dibawah KKM (70) & $39,4 \%$ \\
\hline
\end{tabular}

Nilai rata-rata hasil post test, dapat dihitung dari :

$\dot{X}=\frac{\sum X}{\sum N}$, Jadi $\dot{X}=\frac{2385}{33}=72,3$

Nilai $\mathrm{KKM}=70$. Jadi sudah ada peningkatan prestasi belajar, namun hanya sedikit.

Jawaban Ketuntasan Individu (prestasi belajar siswa) $=$

$\frac{\sum \text { siswa yang mendapat nilai } \geq 70}{\sum \text { siswa }} \times 100 \%$

Jadi, Ketuntasan Individu (prestasi belajar siswa) $=\frac{20}{30} \times 100 \%=60,6 \%$

Masih kurang dari indicator pencapaian siklus I sebesar $85 \%$ atau lebih. Maka dilanjutkan percobaan pembelajaran dengan metode problem based learning pada siklus II.

Tabel berikut adalah daftar frekuensi nilai post test siklus I IPS materi Keunggulan lokasi Indonesia siswa Kelas VIII B SMP Negeri 6 Kota Bima tahun pelajaran 2015/2016 setelah pembelajaran menggunakan metode problem based learning, dengan nilai minimal KKM sebesar 70:

Tabel 3 Daftar Nilai Ulangan Harian Siklus I

\begin{tabular}{|l|l|l|}
\hline Nilai & Frekuensi & Prosentase \\
\hline $0-40$ & 0 & $0.0 \%$ \\
\hline $41-69$ & 13 & $39.4 \%$ \\
\hline $70-100$ & 20 & $60.6 \%$ \\
\hline Jumlah & 33 & $100 \%$ \\
\hline
\end{tabular}

Dari tabel diatas dapat kita lihat terdapat 13 siswa atau $39,4 \%$ yang mendapat nilai antara $41-69$, dan 20 siswa atau 60,6\% yang mendapat nilai antara 70 - 100. Dengan ketentuan nilai KKM 70, dapat disimpulkan jika pencapaian prestasi nilai 70 - 100, maka prestasi belajar siswa telah meningkat dari $30,3 \%$ menjadi $60,6 \%$. Namun karena belum mencapai target indicator pencapaian siklus I sebesar $85 \%$ atau lebih, maka akan dilanjutkan ke Siklus II.

Selain itu, dari proses wawancara diperoleh kesimpulan bahwa beberapa siswa menjadi bersemangat dalam belajar IPS, karena pelaksanaan kegiatan belajar IPS yang menggunakan pendekatan problem based learning ini dilaksanakan dengan langsung melibatkan siswa secara aktif dan mandiri, dan melaksanakan kegiatan bersama kelompok sehingga lebih ringan. Meskipun masih terdapat kendala-kendala seperti yang telah diuraikan dalam laporan observasi. Dari hasil post test, 20 nilai siswa telah sesuai $\mathrm{KKM}$ atau diatas nilai 70. Sedangkan 13 siswa dari 33 siswa belum berhasil. Karena nilai siswa berada di bawah 70. Siswa yang mendapat nilai di bawah 70 .

\section{Siklus II}

Dalam pelaksanaan proses pembelajaran, Guru telah melaksanakan perbaikan dari siklus I, siswa sudah mengalami kemajuan dan pelaksanaan-pun 
telah berjalan baik. Namun Guru menemukan masalah baru dalam pelaksanaan siklus II, yaitu: (1) Terdapat beberapa kelompok yang lupa membawa peta wilayah Indonesia, sehingga suasana kelas menjadi gaduh karena saing meminjam dari kelompok yang lain. (2) Masih terdapat 3 (tiga) siswa yang malu dalam presentasi dan kurang aktif dalam diskusi kelompok.

Adapun prosentase hasil observasi dalam pelaksanaan percobaan pada siklus II dapat dilihat dari tabel bawah ini. Perhitungan prosentase keberhasilan siklus II di bawah ini diskusikan juga dengan teman sejawat.

Tabel 4 Prosentase Hasil Observasi Siklus II

\begin{tabular}{|l|l|l|}
\hline No & Kegiatan Siswa & Prosentase \\
\hline 1 & Kelengkapan menyiapkan alat dan bahan percobaan & $90 \%$ \\
\hline 2 & Keruntutan langkah-langkah dalam pelaksanaan kegiatan percobaan & $85 \%$ \\
\hline 3 & Keaktifan siswa selama melaksanakan kegiatan percobaan & $89 \%$ \\
\hline 4 & Keaktifan siswa dalam mengutarakan pendapat saat berdiskusi & $87 \%$ \\
\hline 5 & Kesimpulan akhir sesuai percobaan & $88 \%$ \\
\hline
\end{tabular}

Hasil post test pada siklus kedua dapat menjadi perhitungan persentase peningkatan hasil belajar siswa. Dengan acuan penilaian tetap berdasarkan nilai KKM yang telah ditetapkan yaitu paling sedikit siswa memperoleh nilai 70 . Adapun rekapitulasi hasil test siklus II adalah sebagai berikut:

Tabel 5 Hasil Post Test Siklus Kedua

\begin{tabular}{|l|l|l|}
\hline No & Deskripsi & Nilai \\
\hline 1 & Jumlah Nilai & 2735 \\
\hline 2 & Rata-rata Hasil Post Test & 82,9 \\
\hline 3 & Jumlah siswa yang mendapat nilai diatas KKM (70) & 30 \\
\hline 4 & Presentase siswa yang mendapat nilai diatas KKM (70) & $90,9 \%$ \\
\hline 5 & Jumlah siswa yang mendapat nilai dibawah KKM (70 & 3 \\
\hline 6 & Presentase siswa yang mendapat nilai dibawah KKM (70) & $9,1 \%$ \\
\hline
\end{tabular}

Nilai rata-rata hasil post test, dapat dihitung dari :

$\dot{X}=\frac{\sum X}{\sum N}$, Jadi $\dot{X}=\frac{2735}{33}=82,9$

Nilai $\mathrm{KKM}=70$. Jadi sudah ada peningkatan prestasi belajar yang signifikan.

Jawaban Ketuntasan Individu (prestasi belajar siswa) =

$\frac{\sum \text { siswa yang mendapat nilai } \geq 70}{\sum \text { siswa }} \times 100 \%$

Jadi, Ketuntasan Individu (prestasi belajar siswa) $=\frac{30}{33} \times 100 \%=90,9 \%$

Telah mencapai indicator pencapaian siklus II sebesar $85 \%$ atau lebih. Maka tidak perlu dilanjutkan percobaan pembelajaran dengan pendekatan problem based learning pada siklus III.

Tabel berikut adalah daftar frekuensi nilai post test siklus II IPS materi Keunggulan lokasi Indonesia siswa Kelas VIII B SMP Negeri 6 Kota Bima tahun 2015/2016 setelah pembelajaran menggunakan metode problem based learning siklus II, dengan nilai minimal KKM sebesar 70:

Tabel 6 Daftar Nilai Ulangan Harian Siklus II 


\begin{tabular}{|l|l|l|}
\hline Nilai & Frekuensi & Prosentase \\
\hline $0-40$ & 0 & $0.0 \%$ \\
\hline $41-69$ & 3 & $9.1 \%$ \\
\hline $70-100$ & 30 & $90.9 \%$ \\
\hline Jumlah & 33 & $100 \%$ \\
\hline
\end{tabular}

Dari tabel diatas dapat kita lihat terdapat 3 siswa atau $9,1 \%$ yang mendapat nilai antara $41-69$, dan 30 siswa atau 90,9\% yang mendapat nilai antara 70 - 100. Dengan ketentuan nilai KKM 70, dapat disimpulkan jika pencapaian prestasi nilai $70-100$, maka prestasi belajar siswa telah meningkat dari $60,6 \%$ menjadi $90,9 \%$. Dengan $90,9 \%$ maka telah tercapai indicator pencapaian siklus II sebesar yang $85 \%$ atau lebih, maka tidak perlu dilanjutkan ke Siklus III.

Selain itu, dari proses wawancara diperoleh kesimpulan bahwa beberapa siswa menjadi bersemangat dalam belajar IPS, karena pelaksanaan kegiatan belajar IPS yang bermetode pendekatan problem based learning ini dilaksanakan dengan membawa alat pembelajaran sendiri, dan melaksanakan kegiatan bersama kelompok sehingga mereka lebih rileks dan ringan dalam mengerjakan laporan kegiatan. Meskipun masih terdapat kendala-kendala seperti yang telah diuraikan dalam laporan observasi.

\section{PEMBAHASAN}

Berdasarkan hasil pelaksanaan pada siklus I, II dapat dinyatakan bahwa terjadi peningkatan kualitas pembelajaran yang tampak dan perolehan hasil evaluasi dan keaktifan siswa. Dari tabel 4.2 dan gambar 4.2 siklus I hasil observasi menunjukkan, prosentase keberhasilan kelengkapan menyiapkan alat dan bahan percobaan $30 \%$, prosentase keruntutan langkah-langkah yang ditempuh dalam pelaksanaan percobaan $52 \%$, prosentase keaktifan siswa dalam melaksanakan kegiatan percobaan $57 \%$, prosentase keaktifan siswa dalam mengutarakan pendapat saat berdiskusi $43 \%$ dan prosentase hasil penarikan kesimpulan akhir sesuai percobaan $46 \%$.

Berdasarkan tabel 4.5 dan gambar 4.4 siklus II hasil observasi menunjukkan, prosentase keberhasilan metode kelengkapan menyiapkan alat dan bahan percobaan siswa yang disiapkan $90 \%$, prosentase keruntutan langkahlangkah yang ditempuh dalam pelaksanaan percobaan $85 \%$, prosentase keaktifan siswa dalam melaksanakan kegiatan percobaan $89 \%$, prosentase keaktifan siswa dalam mengutarakan pendapat saat berdiskusi $87 \%$ dan prosentase hasil penarikan kesimpulan akhir sesuai percobaan $88 \%$.

Dari daftar nilai (lihat lampiran) dapat kita lihat adanya prosentase kenaikan nilai IPS mulai dari kondisi awal pra tindakan, diketahui baru 10 siswa atau 30,3\% yang mengalami ketuntasan belajar dan mendapatkan nilai sesuai dengan KKM. Hasil evaluasi siklus I menunjukkan baru 20 siswa atau 60,6\% yang mengalami ketuntasan belajar dan mendapat nilai sama dengan atau di atas KKM yaitu 70. Hal itu menunjukkan bahwa pelaksanaan siklus I belum mencapai keberhasilan karena indikator pencapaianrnya adalah sebesar $85 \%$ atau lebih. Siklus II menunjukkan ada 30 siswa atau 90,9\% dari 33 siswa yang mengalami ketuntasan belajar. Sehingga peneliti menyimpulkan bahwa pada siklus II ini 
peneliti telah mencapai keberhasilan dari penelitian tindakan kelas yang telah dilakukan.

Ketika peneliti melaksanakan siklus I, peneliti mengalami berbagai kendala antara lain banyak dari kelompok yang kekurangan sumber referensi untuk mengerjakan lembar kegiatan. Masih ada kelompok yang bingung dalam mengikuti langkah-langkah yang tertera dalam lembar kegiatan. Masih ada beberapa siswa yang belum aktif dalam pelaksanaan percobaan. Ketika pelaksanaan diskusi, ada beberapa siswa yang tidak aktif menyampaikan pendapatnya. Dalam menyimpulkan hasil percobaan, terdapat 4 (empat) kelompok yang malu untuk presentasi, dan hanya terdapat 2 (dua) siswa yang mengajukan pertanyaan.

Peneliti kemudian melaksanakan siklus II sebagai perbaikan siklus I, sebelum pelaksanaan siklus II ini peneliti mengganti rencana pembelajaran metode problem based learning baru yaitu dengan memberikan tugas kepada masing-masing siswa untuk membawa peta dan mengamati posisi silang wilayah Indonsia kemudian mencari keuntungan letak Indonesia pada posisi silang dua benua dan dua samudera tersebut.

Dalam pelaksanaan percobaan, peneliti senantiasa memberi bimbingan untuk siswanya dalam melaksanakan langkah-langkah sesuai lembar kegiatan. Peneliti pun memberi bimbingan siswa saat berdiskusi untuk menarik kesimpulan. Dengan adanya motivasi guru berupa reward, siswa telah terlihat aktif dalam kegiatan pembelajaran dalam melaksanakan percobaan, presentasi di depan kelas dan berdiskusi menarik kesimpulan. Meskipun ada kendala yaitu terdapat beberapa kelompok yang lupa membawa peta sehingga mereka gaduh karena harus meminjam peta dari kelompok lain., namun dengan hasil prestasi belajar yang dicapai dapat disimpulkan bahwa penelitian tindakan kelas dari siklus II ini telah berhasil.

\section{KESIMPULAN}

Berdasarkan hasil penelitian tindakan kelas yang telah dilaksanakan dalam 2 siklus dengan menerapkan pendekatan problem based learning dalam pembelajaran IPS pada siswa Kelas VIII B SMP Negeri 6 Kota Bima tahun 2015/2016 ini, dapat dibuat kesimpulan sebagai berikut : Penerapan pendekatan problem based learning dapat meningkatkan hasil belajar IPS siswa Kelas VIII B SMP Negeri 6 Kota Bima. Adanya perubahan kenaikan prosentase dalam menyiapkan alat dan bahan, keruntutan langkah-langkah siswa dalam melaksanakan percobaan, keaktifan siswa dalam melaksanakan kegiatan percobaan, keaktifan siswa ketika berdiskusi dan hasil akhir atau simpulan yang diperoleh dari hasil kegiatan diskusi.

\section{SARAN}

Berdasarkan hasil penelitian, maka ada beberapa saran yang dapat dipergunakan sebagai bahan pertimbangan dan sebagai bahan uraian penutup penelitian tindakan kelas ini, antara lain: (1) Bagi Guru, Hendaknya mempersiapkan secara cermat perangkat pendukung pembelajaran dan fasilitas belajar yang diperlukan, karena sangat mempengaruhi efektivitas dan efisiensi pembelajaran yang pada akhirnya berpengaruh pada proses dan hasil belajar IPS siswa. (2) Bagi Siswa, Hendaknya ikut berperan aktif dalam proses pembelajaran, 
selalu mengerjakan tugas-tugas yang diberikan guru dan meningkatkan usaha belajar sehingga dapat memperoleh prestasi yang diharapkan. (3) Bagi Sekolah, Hendaknya mengupayakan pengadaan berbagai media pembelajaran IPS untuk kelas rendah, baik bantuan maupun swadaya sekolah, sehingga lebih menunjang dalam penanaman konsep-konsep IPS secara lebih nyata sekaligus meningkatkan aktivitas belajar siswa.

\section{DAFTAR RUJUKAN}

Barrows. 1982. The Tutors (Teachers) Role in Problem-Based Learning Curriculum. (Online), (http;//edaff.siumed.edu).

Boud, D. \& Felleti, G.I. 1997. The Challenge of Problem Based Learning. Londong: Kogapage

Dimyati,. \& Mudjiono. 2006. Belajar dan Pembelajaran. Jakarta: Rineka Cipta.

Sudjana, N. 2009. Penilaian Hasil Proses Belajar Mengajar. Bandung: Remaja Rosdakarya. 